\title{
REVIEW ARTICLE \\ Chlamydia psittaci (psittacosis) as a cause of community-acquired pneumonia: a systematic review and meta-analysis
}

\author{
L. HOGERWERF ${ }^{1}$, B. DE GIER ${ }^{1}$, B. BAAN ${ }^{1,2}$ AND W. VAN DER HOEK ${ }^{1}$ \\ ${ }^{1}$ National Institute for Public Health and the Environment, Centre for Infectious Disease Control, Antonie van \\ Leeuwenhoeklaan 9, 3721 MA Bilthoven, the Netherlands \\ ${ }^{2}$ VU University Amsterdam, Athena Institute, De Boelelaan 1105, $1081 \mathrm{HV}$ Amsterdam, the Netherlands
}

Received 6 March 2017; Final revision 17 July 2017; Accepted 16 August 2017;

first published online 26 September 2017

\section{SUMMARY}

Psittacosis is a zoonotic infectious disease caused by the transmission of the bacterium Chlamydia psittaci from birds to humans. Infections in humans mainly present as community-acquired pneumonia (CAP). However, most cases of CAP are treated without diagnostic testing, and the importance of $C$. psittaci infection as a cause of CAP is therefore unclear. In this meta-analysis of published CAP-aetiological studies, we estimate the proportion of CAP caused by C. psittaci infection. The databases MEDLINE and Embase were systematically searched for relevant studies published from 1986 onwards. Only studies that consisted of 100 patients or more were included. In total, 57 studies were selected for the meta-analysis. $C$. psittaci was the causative pathogen in $1.03 \%(95 \%$ CI $0.79-1 \cdot 30)$ of all CAP cases from the included studies combined, with a range between studies from 0 to $6 \cdot 7 \%$. For burden of disease estimates, it is a reasonable assumption that $1 \%$ of incident cases of CAP are caused by psittacosis.

Key words: Aetiology, Chlamydia psittaci, community-acquired pneumonia, psittacosis.

\section{INTRODUCTION}

Psittacosis is an infectious disease caused by the bacterium Chlamydia psittaci. Human cases of infection can occur via the inhalation of contaminated aerosols originating from urine, faeces, or other excretions from infected birds [1]. Infection with Chlamydia psittaci is mainly described in situations that entail close contact with birds. This includes pet shops, veterinary hospitals, and bird shows [2-4]. Furthermore, C. psittaci infections are reported in poultry, with human cases linked to occupational exposure in the poultry industry [5-7].

\footnotetext{
* Author for correspondence: L. Hogerwerf, Centre for Infectious Disease Control (CIb), National Institute for Public health and the Environment (RIVM), Antonie van Leeuwenhoeklaan 9, P.O. Box 1, 3720 BA Bilthoven, the Netherlands. (Email: lenny.hogerwerf@rivm.nl)
}

Upon successful transmission to humans, $C$. psittaci mainly presents as a non-specific flu-like illness or 'community-acquired pneumonia' (CAP) [1]. However, the proportion of CAP cases caused by C. psittaci is unclear. Diagnostic tests for C. psittaci are rarely done when patients present with CAP [8]. This is in line with prevailing guidelines for general practitioners and medical specialists in countries such as the USA, the UK, and the Netherlands that microbiological investigation is not necessary for adequate treatment of uncomplicated pneumonia [8]. However, this implies that the individual patient with $C$. psittaci pneumonia might not get the optimal treatment. For example, the common presumptive treatment for CAP in the Netherlands is amoxicillin, which is not effective against $C$. psittaci. In addition, from a public health point of view it is important to trace the source of any human psittacosis case. 


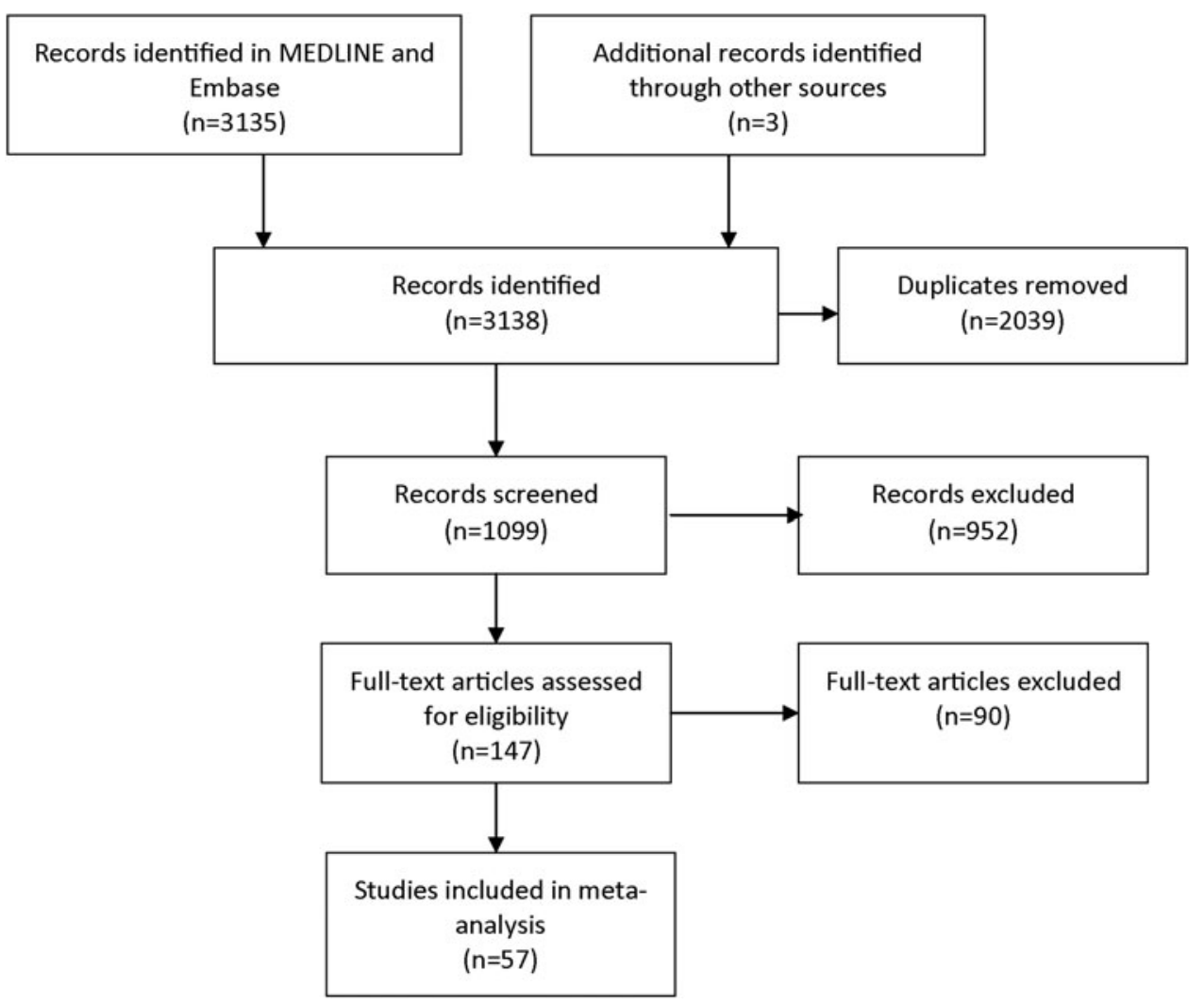

Fig. 1. Selection of publications for the review and meta-analysis.

Linking to animal sources requires both human and animal or environmental polymerase chain reaction (PCR)-based diagnostics with ensuing genotyping of isolates [9], as well as veterinary and epidemiological investigation.

The present study was done in the context of an integrated veterinary-human health project entitled Plat $4 \mathrm{~m}-2 \mathrm{Bt}-\mathrm{psittacosis}$. Two of the aims of this project are to reduce the diagnostic deficit of psittacosis in humans by implementing a harmonised respiratory diagnostic PCR method in medical microbiological laboratories, and to determine the disease burden from psittacosis in humans. A psittacosis disease burden calculation requires information on the incidence of psittacosis, which is currently not available. The objective of the present review is therefore to assess the contribution of $C$. psittaci in the aetiology of CAP in order to obtain a best possible estimate of the real incidence of psittacosis.

\section{METHODS}

The focus of this systematic review and meta-analysis was on CAP-aetiological studies that included laboratory diagnostics for $C$. psittaci. We selected articles from MEDLINE and Embase in March 2015. The following key terms, and multiple synonyms hereof, were used to build the search strategy: 'psittacosis', 'Chlamydia psittaci', 'Chlamydophila psittaci', 'ornithosis', 'pneumonia', 'community-acquired pneumonia', 'incidence', 'causative pathogens'. During first screening, studies included were those published from 1986 onwards. In studies before 1986, no distinction was possible between infections caused by $C$. psittaci and $C$. pneumoniae, which has a human-to-human transmission route [10]. A further prerequisite for inclusion was that the research population comprised 100 patients or more. Another prerequisite was that the study had to be written in English, Dutch, German, or Spanish. Exclusion criteria during full text assessment for eligibility were a lack of a full text, not being a CAP-aetiological study, no information on C. psittaci, no specification of the Chlamydia spp., and not presenting original data. Figure 1 shows the search strategy according to PRISMA guidelines [11]. The three additional publications were identified through fellow researchers. Data were extracted about the size of the study population that was tested for C. psittaci, and about the number of $C$. psittaci detections, the diagnostic test used, the location, and year 
Table 1. Details of studies included in the review and meta-analysis

\begin{tabular}{|c|c|c|c|c|c|c|}
\hline Year of study & Location & Test used & $\begin{array}{l}\text { Study } \\
\text { population } \\
(N)\end{array}$ & $\begin{array}{l}n(\%) \\
\text { C. psittaci } \\
\text { infections }\end{array}$ & Reference & Comments \\
\hline 1980-1981 & Switzerland & $\mathrm{CF}$ & 1494 & $29(1 \cdot 9)$ & {$[13]$} & \\
\hline 1981-1982 & Finland & IF & 304 & $3(1 \cdot 0)$ & [14] & \\
\hline $1982-1983$ & Sweden & $\mathrm{CF}$ & 327 & $1(0 \cdot 3)$ & [15] & $\begin{array}{l}\text { Only children }<15 \\
\text { years }\end{array}$ \\
\hline 1982-1983 & Britain & $\mathrm{CF}$ & 453 & $13(2 \cdot 9)$ & [16] & \\
\hline 1982-1984 & Sweden & $\mathrm{CF}$ & 180 & $6(3 \cdot 3)$ & [17] & \\
\hline 1983 & Saudi Arabia & $\mathrm{CF}$ & 112 & $2(1 \cdot 8)$ & [18] & \\
\hline 1983-1984 & Spain & $\mathrm{CF}$ & 405 & $14(3 \cdot 5)$ & [19] & \\
\hline 1985-1986 & Spain & $\mathrm{CF}$ & 510 & $1(0 \cdot 2)$ & [20] & \\
\hline 1985-1988 & Spain & $\mathrm{CF}$ & 168 & $1(0 \cdot 6)$ & [21] & \\
\hline 1986-1987 & Finland & IF & 136 & $3(2 \cdot 2)$ & [22] & \\
\hline 1987 & Sweden & IF & 277 & $3(1 \cdot 1)$ & [23] & \\
\hline 1987-1988 & Australia & $\mathrm{CF}$ & 267 & $7(2 \cdot 6)$ & [24] & \\
\hline 1987-1989 & Ethiopia & $\mathrm{CF}$ & 103 & $4(3 \cdot 9)$ & [25] & \\
\hline 1987-1989 & France & $\mathrm{CF}$ & 132 & $1(0 \cdot 8)$ & [26] & \\
\hline 1987-1995 & Spain & $\mathrm{CF}$ & 416 & $1(0 \cdot 2)$ & [27] & \\
\hline 1989-1990 & Japan & IF & 139 & $0(0)$ & [28] & $\begin{array}{l}\text { Only children }<15 \\
\text { years }\end{array}$ \\
\hline 1990-1992 & Australia & IF & 280 & $0(0)$ & [29] & $\begin{array}{l}\text { Only children }<5 \\
\text { years }\end{array}$ \\
\hline 1990-1993 & Nordic countries & IF & 383 & $4(1)$ & {$[30]$} & \\
\hline 1991 & Papua New Guinea & $\mathrm{CF}$ & 131 & $0(0)$ & [31] & \\
\hline 1991 & Saudi Arabia & $\mathrm{CF}$ & 341 & $1(0 \cdot 3)$ & {$[32]$} & \\
\hline 1991-1992 & Italy & $\mathrm{CF}$ & 179 & $12(6 \cdot 7)$ & [33] & \\
\hline 1991-1994 & Canada & IF & 149 & $2(1 \cdot 3)$ & [34] & \\
\hline 1992 & Spain & IF & 165 & $2(1 \cdot 2)$ & {$[35]$} & \\
\hline 1992 & Britain & CF, ELISA & 275 & $4(1 \cdot 5)$ & {$[36]$} & \\
\hline 1992 & Croatia & $\mathrm{CF}$ & 581 & $16(2 \cdot 8)$ & {$[37]$} & \\
\hline 1992-1994 & France & IF & 104 & $1(1)$ & [38] & $\begin{array}{l}\text { Only children }<13 \\
\text { years }\end{array}$ \\
\hline 1994-1997 & Japan & $\mathrm{CF}$ & 326 & $7(2 \cdot 1)$ & [39] & \\
\hline 1995-1997 & Spain & IF & 533 & $5(0 \cdot 9)$ & [40] & \\
\hline 1995-2000 & Réunion & IF & 112 & $0(0)$ & [41] & $\begin{array}{l}\text { Only patients in } \\
\text { intensive care }\end{array}$ \\
\hline 1995-2001 & Spain & IF & 1474 & $16(1 \cdot 1)$ & {$[42]$} & \\
\hline 1995-2005 & Spain & IF & 1556 & $17(1 \cdot 1)$ & {$[43]$} & \\
\hline 1996-1997 & Spain & $\begin{array}{l}\text { Serology not } \\
\text { specified }\end{array}$ & 395 & $2(0 \cdot 5)$ & {$[44]$} & \\
\hline 1996-1997 & Slovenia & $\mathrm{CF}$ & 211 & $2(0 \cdot 9)$ & {$[45]$} & \\
\hline 1996-1997 & England & PCR & 244 & $1(0 \cdot 4)$ & [46] & \\
\hline 1996-1999 & Spain & IF & 221 & $4(1 \cdot 8)$ & {$[47]$} & \\
\hline 1997-1998 & Argentina & IF & 346 & $1(0 \cdot 3)$ & [48] & \\
\hline 1997-2000 & Spain & IF & 247 & $3(1 \cdot 2)$ & [49] & \\
\hline 1999-2000 & Japan & IF & 232 & $5(2 \cdot 2)$ & {$[50]$} & \\
\hline 1999-2001 & Slovenia & IF & 109 & $1(0 \cdot 9)$ & {$[51]$} & \\
\hline 1999-2001 & Spain & IF & 493 & $9(1 \cdot 8)$ & {$[52]$} & \\
\hline 1999-2002 & Sweden & $\mathrm{IF}$ & 235 & $3(1 \cdot 3)$ & [53] & \\
\hline $2000-2001$ & $\begin{array}{l}6 \text { countries in Eastern } \\
\text { Europe }\end{array}$ & IF & 180 & $3(1 \cdot 7)$ & [54] & \\
\hline 2000-2004 & Spain & $\mathrm{CF}$ & 911 & $4(0 \cdot 4)$ & {$[55]$} & \\
\hline 2001-2002 & Korea & IF & 126 & $0(0)$ & {$[56]$} & \\
\hline 2001-2004 & Japan & $\mathrm{CF}$ & 349 & $1(0 \cdot 3)$ & [57] & \\
\hline 2002 & Spain & $\begin{array}{l}\text { Serology not } \\
\text { specified }\end{array}$ & 204 & $1(0 \cdot 5)$ & [58] & \\
\hline
\end{tabular}


Table 1 (cont.)

\begin{tabular}{|c|c|c|c|c|c|c|}
\hline Year of study & Location & Test used & $\begin{array}{l}\text { Study } \\
\text { population } \\
(N)\end{array}$ & $\begin{array}{l}n(\%) \\
\text { C. psittaci } \\
\text { infections }\end{array}$ & Reference & Comments \\
\hline 2002-2011 & Japan & $\begin{array}{l}\text { Serology not } \\
\text { specified }\end{array}$ & 1032 & $15(1 \cdot 5)$ & [59] & \\
\hline 2003-2005 & Chile & IF & 176 & $0(0)$ & {$[60]$} & \\
\hline 2004-2006 & Australia & IF, ELISA & 885 & $2(0 \cdot 2)$ & [61] & \\
\hline 2005-2009 & Pan-European & Not specified & 1166 & $10(0 \cdot 9)$ & [62] & $\begin{array}{l}\text { Only patients in } \\
\text { intensive care }\end{array}$ \\
\hline 2005-2011 & Japan & Culture, IF & 786 & $5(0 \cdot 6)$ & {$[63]$} & \\
\hline 2006 & Turkey & IF & 100 & $1(1)$ & [64] & $\begin{array}{l}\text { Only children }<12 \\
\text { years }\end{array}$ \\
\hline 2006-2007 & Spain & IF & 663 & $2(0 \cdot 3)$ & {$[65]$} & \\
\hline $2007-2010$ & Netherlands & $\mathrm{PCR}, \mathrm{CF}, \mathrm{IF}$ & 147 & $7(4 \cdot 8)$ & {$[66]$} & \\
\hline 2007-2010 & Netherlands & $\begin{array}{l}\text { Serology not } \\
\text { specified }\end{array}$ & 339 & $3(0 \cdot 9)$ & {$[67]$} & \\
\hline 2008-2009 & Netherlands & PCR, CF & 408 & $7(1 \cdot 7)$ & {$[68]$} & \\
\hline 2011-2012 & Germany & PCR & 780 & $17(2 \cdot 2)$ & [69] & \\
\hline
\end{tabular}

$\mathrm{CF}$, complement fixation test; ELISA, enzyme-linked immunosorbent assay; IF, immunofluorescence test; PCR, polymerase chain reaction.

of study. To estimate the overall proportion of CAP caused by $C$. psittaci infections, random-effects meta-analysis for proportions was performed using 'metaprop_one' package in Stata version 13, with Freeman-Tukey transformation to stabilise variances, weighting by study size, stratified by type of laboratory diagnosis [12].

\section{RESULTS}

The literature search yielded 147 studies that seemed eligible for full-text review (Fig. 1). During full text review, a total of 90 articles was excluded because the full text could not be found $(n=10)$ or provided no information on $C$. psittaci $(n=49)$, or was not a CAP-aetiological study $(n=5)$ or provided no original data $(n=10)$ or the Chlamydia spp. was not specified $(n=16)$. This resulted in the inclusion of 57 relevant studies, with a proportion of CAP caused by $C$. psittaci, ranging from 0 to $6.7 \%$ (Table 1). Based on the meta-analysis, C. psittaci was the causative pathogen in $1.03 \%(95 \%$ CI $0.79-1 \cdot 30)$ of all cases with CAP that were tested for $C$. psittaci infection in these 57 studies (Fig. 2).

There are clear changes over time in diagnostic methods used, and in proportion of CAP reported to be caused by $C$. psittaci. The older studies, including those that were done before 1986, but published from 1986 onwards, were mostly based on complement fixation tests (CF) and reported the highest proportions, with the largest variability between studies (Figs 2 and 3). CF was used in 23 of the included studies but seems to have been replaced by (micro) immunofluorescence (MIF/IF) as the serological test of choice in more recent CAP-aetiological studies. PCR was used in only four of the later studies. Based on PCR results reported in these four studies only, the reported incidence of $C$. psittaci in CAP is $1 \cdot 8 \%$. For this PCR-based estimate, only PCR outcomes of the studies were used and CF or IF outcomes that were reported in two of these four studies (classified as 'mixed or other' in Figs 2 and 3) were ignored.

\section{DISCUSSION}

This review shows that approximately $1 \%$ of annual CAP is caused by $C$. psittaci infection. The estimated proportion of $C$. psittaci in CAP was remarkably uniform across the wide variety of studies included in this review and meta-analysis. The group of studies using $\mathrm{CF}$ formed an exception, with high variability in the reported proportions, and generally higher proportions of positives. This may be explained by cross-reactivity, for instance with $C$. pneumoniae. Also, some of the included studies were restricted to certain age groups (e.g. children) or patient groups (e.g. intensive care patients), making pooling of the data problematic. Therefore, we repeated the meta-analysis with tighter inclusion criteria, excluding all studies that used only 


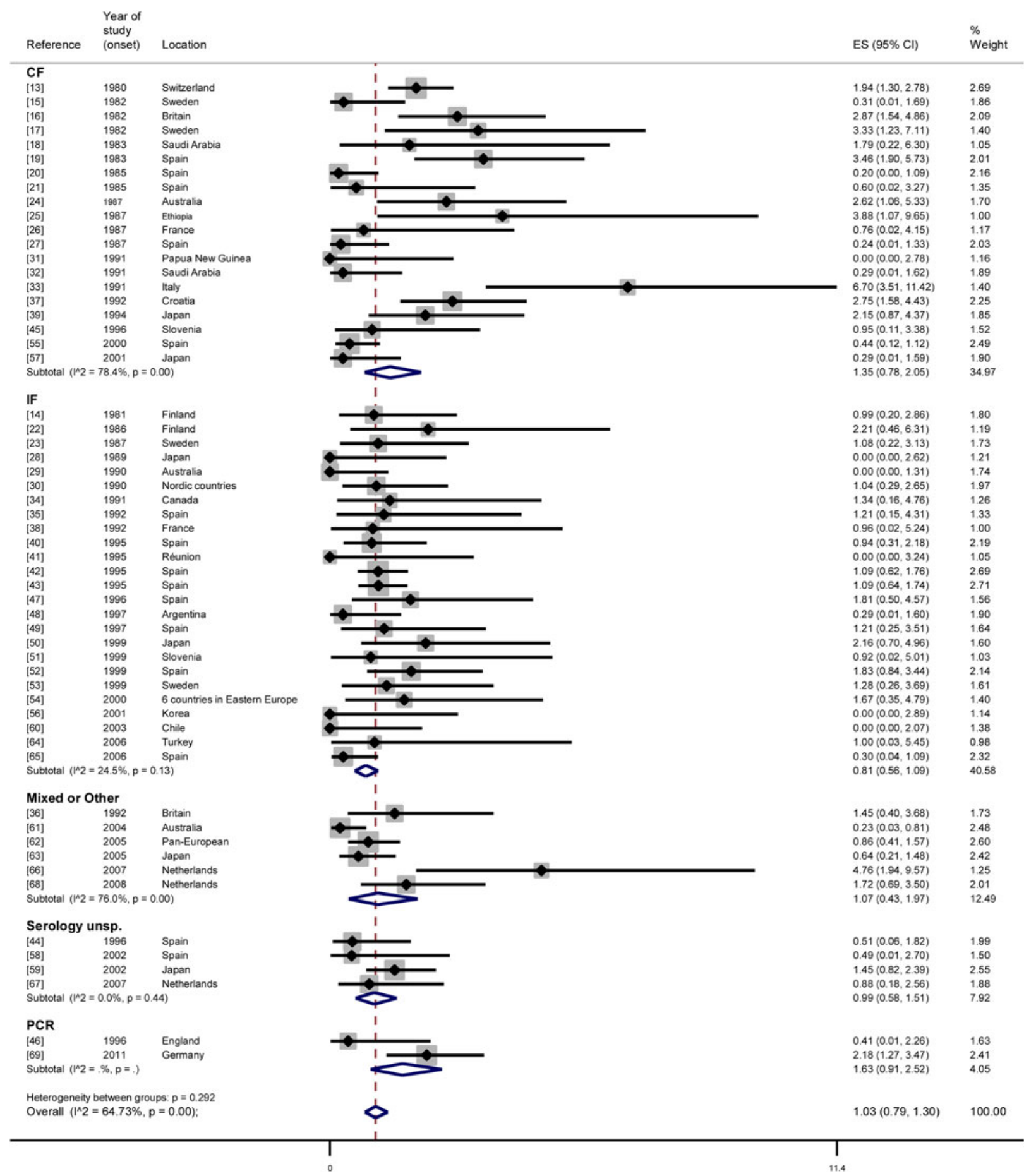

Fig. 2. Forest plot of meta-analysis of the proportion of CAP caused by Chlamydia psittaci infections, stratified by type of laboratory diagnosis.

CF $(n=20)$, all studies in children or intensive care patients $(n=7$, of which 1 with $C F)$, and all studies with an onset before 1986 (1 used IF, the others used CF). In this meta-analysis with tighter inclusion criteria, the estimated overall proportion remained approximately $1 \%$ (presented in online
Supplementary Fig. S1). Another limitation of the present review and meta-analysis is that atypical causative agents in CAP including C. psittaci have been shown to be associated with the non-respiratory season (i.e. late spring, summer, and early autumn in Europe), age $<60$ years, and male gender [70], and contact with 

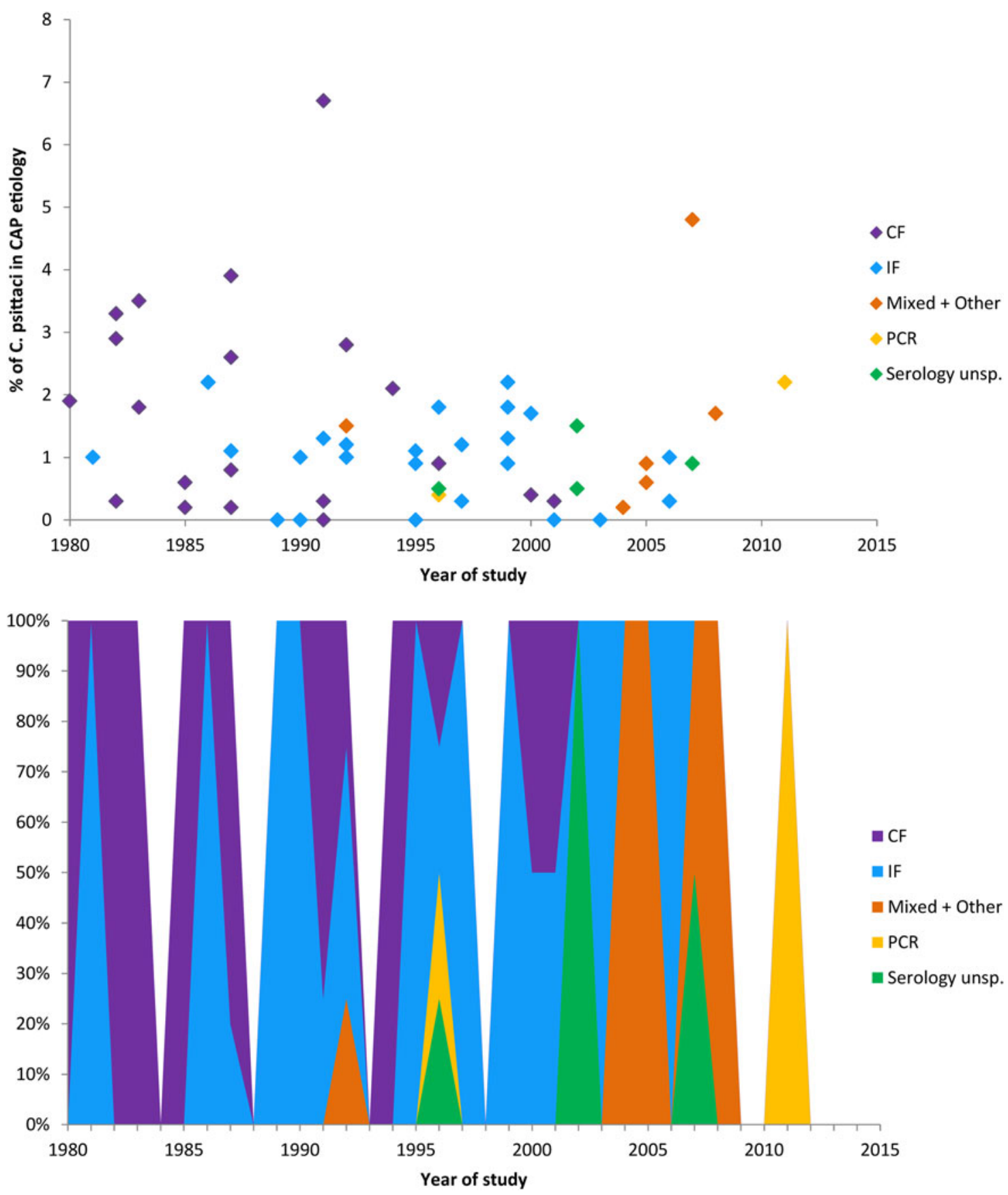

Fig. 3. Proportion of CAP caused by Chlamydia psittaci in different studies over time and by type of laboratory diagnosis (top panel), and contribution of each type of laboratory diagnosis to the total over time (bottom panel). In the top panel, each symbol represents a study and the according percentage of CAP patients in which $C$. psittaci was found. The varying colours indicate the diagnostic methods that were used. CF, complement fixation test; IF, immunofluorescence test; 'unsp.', unspecified; PCR, polymerase chain reaction. In the bottom panel, the filled colours represent the contribution of each type of laboratory diagnosis to the total over time, expressed in percentages. 'Year of study' represents the year in which the gathering of data commenced. Although studies published before 1986 were not included, the period in which patient data had been gathered usually differed from the year of publication.

birds. Unfortunately, there was insufficient information for season-, age-, and gender-specific estimates. The risk of exposure to $C$. psittaci is likely to differ across geographical areas. Included studies originated from multiple countries, mostly in Europe, and particularly Spain $(n=15)$. Nevertheless, the heterogeneity across studies was remarkably low, and the estimate of approximately $1 \%$ of CAP being caused by $C$. psittaci 
was remarkably robust, given the large variation between the studies regarding geographical location, season, diagnostic tests, study population, and the varying (and often not reported) case definitions for CAP and $C$. psittaci infection.

CAP is a very common condition in all countries of the world. For example, in the Netherlands during the years 2008-2011, the mean annual number of CAP episodes treated in hospitals was 48843 [71]. Based on the present review one would expect an annual number of 503 hospitalised CAP patients with psittacosis. If based on the four studies using PCR only, of which three originate from the Netherlands, one would expect an annual number of 879 hospitalised CAP patients with psittacosis. The national infectious diseases surveillance system showed only 93 notified psittacosis patients on average per year over the period 2008-2011, including non-hospitalised cases. The estimation based on the present review therefore entails an incidence of psittacosis that is at least five times higher than the reported figure in the Netherlands.

In many countries, including the Netherlands, most CAP patients are managed in primary care [72]. However, the CAP-aetiological studies included in the current review were almost entirely done among hospitalised patients. The importance of psittacosis among pneumonia patients in primary care therefore remains elusive, as the proportion of $C$. psittaci may be different from hospitalised pneumonia patients [33]. Furthermore, although CAP is likely to be the most important clinical presentation of an infection with $C$. psittaci, it is not the only one [1,73]. Other clinical presentations are also possible upon infection with $C$. psittaci, including severe presentations such as sepsis [4]. Follow-up studies on the burden of psittacosis, that may use the results of our meta-analysis, would need to take into account other clinical presentations as well.

More frequent testing of CAP patients is recommended to reduce the diagnostic deficit and under-ascertainment. The trend over time in which serological methods are replaced by PCR-based methods is important from a public health point of view as PCR during the acute episode is a very specific method, although less sensitive if the diagnosis is only considered later in the disease episode. Positive samples could be genotyped and matched with animal and environmental samples. Currently, all medical microbiology laboratories in the Netherlands are encouraged to implement PCR-based diagnostics for psittacosis and to send isolates to one laboratory for genotyping [9]. In time, the increased availability of PCR-based methods and the increased costeffectiveness of the use of these methods in CAP, particularly in the non-respiratory season, could reduce the diagnostic deficit of CAP, provide better data on the burden of disease from psittacosis, and allow for efficient source detection.

\section{SUPPLEMENTARY MATERIAL}

The supplementary material for this article can be found at https://doi.org/10.1017/S0950268817002060

\section{ACKNOWLEDGEMENTS}

The study was funded by the Ministry of Health, Welfare and Sports and from a grant by the Netherlands Organisation for Health Research and Development (ZonMw) to the Plat4m-2Bt-psittacosis project, project number: 522001002 .

\section{AUTHOR'S CONTRIBUTIONS}

$\mathrm{BB}$ conducted the review initiated and designed by WH and LH. WH and LH provided BB with oversight and guidance during the project. BG performed the meta-analysis. All authors reviewed the manuscript critically and contributed with revisions.

\section{REFERENCES}

1. Beeckman DSA, Vanrompay DCG. Zoonotic Chlamydophila psittaci infections from a clinical perspective. Clinical Microbiology and Infection 2009; 15: $11-17$.

2. Halsby KD, et al. Healthy animals, healthy people: zoonosis risk from animal contact in pet shops, a systematic review of the literature. PLoS ONE 2014; 9: e89309.

3. Heddema ER, et al. An outbreak of psittacosis due to Chlamydophila psittaci genotype $\mathrm{A}$ in a veterinary teaching hospital. Journal of Medical Microbiology 2006; 55: 1571-1575.

4. Belchior E, et al. Psittacosis outbreak after participation in a bird fair, Western France, December 2008. Epidemiology and Infection 2011; 139: 1637-1641.

5. Laroucau K, et al. Outbreak of psittacosis in a group of women exposed to Chlamydia psittaci-infected chickens. Eurosurveillance 2015; 20: pii=21155.

6. Dickx V, et al. Chlamydophila psittaci zoonotic risk assessment in a chicken and Turkey slaughterhouse. Journal of Clinical Microbiology 2010; 48: 3244-3250.

7. Vorimore F, et al. Chlamydia psittaci in ducks: a hidden health risk for poultry workers. Pathogens and Disease 2015; 73: 1-9. 
8. van der Hoek W, et al. Extent of the psittacosis problem in humans: the importance of reliable diagnostics [in Dutch]. Infectieziekten Bulletin 2014; 25: 45-48.

9. Heddema ER, et al. Typing of Chlamydia psittaci to monitor epidemiology of psittacosis and aid disease control in the Netherlands, 2008 to 2013. Eurosurveillance 2015; 20: pii=21026.

10. Grayston JT, et al. A new Chlamydia psittaci strain, TWAR, isolated in acute respiratory tract infections. New England Journal of Medicine 1986; 315: 161-168.

11. Moher D, et al. Preferred reporting items for systematic reviews and meta-analyses: the PRISMA statement. PLoS Medicine 2009; 6: e1000097.

12. Nyaga VN, Arbyn M, Aerts M. Metaprop: a Stata command to perform meta-analysis of binomial data. Archives of Public Health 2014; 72: 39.

13. Krech T, et al. Etiology of atypical pneumonias: a serological study on 1494 patients [in German]. Schweizerische Medizinische Wochenschrift 1986; 116: 2-7.

14. Jokinen C, et al. Microbial etiology of communityacquired pneumonia in the adult population of 4 municipalities in eastern Finland. Clinical Infectious Diseases 2001; 32: 1141-1154.

15. Claesson BA, et al. Etiology of community-acquired pneumonia in children based on antibody responses to bacterial and viral antigens. Pediatric Infectious Disease Journal 1989; 8: 856-862.

16. Harrison BDW, et al. Community-acquired pneumonia in adults in British hospitals in 1982-1983: a survey of aetiology, mortality, prognostic factors and outcome. Querterly Journal of Medicine 1987; 62: 195-220.

17. Burman LA, et al. Diagnosis of pneumonia by cultures, bacterial and viral antigen detection tests, and serology with special reference to antibodies against pneumococcal antigens. Journal of Infectious Diseases 1991; 163: 1087-1093.

18. Mohamed ARE, Price Evans DA. The spectrum of pneumonia in 1983 at the Riyadh Armed Forces Hospital. Journal of Infection 1987; 14: 31-37.

19. Ausina V, et al. Prospective study on the etiology of community-acquired pneumonia in children and adults in Spain. European Journal of Clinical Microbiology \& Infectious Diseases 1988; 7: 343-347.

20. Blanquer $\mathbf{J}$, et al. Aetiology of community acquired pneumonia in Valencia, Spain: a multicentre prospective study. Thorax 1991; 46: 508-511.

21. Mensa J, et al. Treatment of atypical pneumonia with josamycin [in Spanish]. Medicina Clínica 1989; 92: 285-287.

22. Ekman MR, et al. Evaluation of serological methods in the diagnosis of Chlamydia pneumoniae pneumonia during an epidemic in Finland. European Journal of Clinical Microbiology \& Infectious Diseases 1993; 12: 756-760.

23. Örtqvist A, et al. Aetiology, outcome and prognostic factors in community-acquired pneumonia requiring hospitalization. European Respiratory Journal 1990; 3: 1105-1113.

24. Lim WS, et al. Study of community acquired pneumonia aetiology (SCAPA) in adults admitted to hospital: implications for management guidelines. Thorax 2001; 56: 296-301.

25. Aderaye G. Community acquired pneumonia in adults in Addis Ababa: etiologic agents and the impact of HIV infection. Tubercle and Lung Disease 1994; 75: 308-312.

26. Moine $\mathbf{P}$, et al. Severe community-acquired pneumonia: etiology, epidemiology, and prognosis factors. Chest 1994; 105: 1487-1495.

27. Almirall $\mathbf{J}$, et al. Differences in the etiology of community-acquired pneumonia according to site of care: a population-based study. Respiratory Medicine 2007; 101: 2168-2175.

28. Ouchi K, et al. Prevalence of chlamydia pneumoniae in acute lower respiratory infection in the pediatric population in Japan. Acta Paediatrica Japonica 1994; 36: 256 260.

29. Torzillo P, et al. Etiology of acute lower respiratory tract infection in Central Australian Aboriginal children. Pediatric Infectious Disease Journal 1999; 18: 714-721.

30. The Nordic Atypical Pneumonia Study Group. Atypical pneumonia in the Nordic countries: aetiology and clinical results of a trial comparing fleroxacin and doxycycline. Journal of Antimicrobial Chemotherapy 1997; 39: 499-508

31. Barnes DJ, et al. The role of viruses and atypical organisms in the pathogenesis of adult pneumonia in Papua New Guinea. Papua New Guinea Medical Journal 1991; 34: 13-16.

32. Dumouchelle MW, Smith KK, Qadri SMH. Respiratory tract infections at a tertiary care centre: a seroepidemiological survey. Medical Science Research 1992; 20: 797-798.

33. Michetti G, et al. Community-acquired pneumonia: is there difference in etiology between hospitalized and out-patients? Minerva Medica 1995; 86: 341-351.

34. Marrie TJ, et al. Ambulatory patients with communityacquired pneumonia: the frequency of atypical agents and clinical course. American Journal of Medicine 1996; 101: 508-515.

35. Pareja A, et al. Etiologic study of patients with community-acquired pneumonia. Chest 1992; 101: 1207-1210.

36. Sillis M, et al. The differentiation of Chlamydia species by antigen detection in sputum specimens from patients with community-acquired acute respiratory infections. Journal of Infection 1992; 25: 77-86.

37. Mlinaric-Galinovic G, et al. Etiology of atypical pneumonia in children and adults. Paediatria Croatica 1995; 39: 247-251.

38. Gendrel D, et al. Etiology and response to antibiotic therapy of pneumonia in French children. European Journal of Clinical Microbiology \& Infectious Diseases 1997; 16: 388-391.

39. Ishida T, et al. Etiology of community-acquired pneumonia in hospitalized patients: a 3-year prospective study in Japan. Chest 1998; 114: 1588-1593.

40. Rosón B, et al. Etiology, reasons for hospitalization, risk classes, and outcomes of community-acquired 
pneumonia in patients hospitalized on the basis of conventional admission criteria. Clinical Infectious Diseases 2001; 33: 158-165.

41. Paganin F, et al. Severe community-acquired pneumonia: assessment of microbial aetiology as mortality factor. European Respiratory Journal 2004; 24: 779-785.

42. Fernández-Sabé N, et al. Community-acquired pneumonia in very elderly patients: causative organisms, clinical characteristics, and outcomes. Medicine (Baltimore) 2013; 82: 159-169.

43. Garcia-Vidal C, et al. Aetiology of, and risk factors for, recurrent community-acquired pneumonia. Clinical Microbiology and Infection 2009; 15: 1033-1038.

44. Ruiz M, et al. Etiology of community-acquired pneumonia: impact of age, comorbidity, and severity. American Journal of Respiratory and Critical Care Medicine 1999; 160: 397-405.

45. Socan M, et al. Microbial aetiology of communityacquired pneumonia in hospitalised patients. European Journal of Clinical Microbiology \& Infectious Diseases 1999; 18: 777-782.

46. Tong CYW, et al. Multiplex polymerase chain reaction for the simultaneous detection of Mycoplasma pneumoniae, Chlamydia pneumoniae, and Chlamydia psittci in respiratory samples. Journal of Clinical Pathology 1999; 52: 257-263.

47. Gutierrez FJA, et al. Prospective study of 221 community acquired pneumonias followed up in an outpatient clinic: etiology and clinical-radiological progression [in Spanish]. Medicina Clinica (Barcelona) 2001; 116: 161-166.

48. Luna CM, et al. Community-acquired pneumonia: etiology, epidemiology, and outcome at a teaching hospital in Argentina. Chest 2000; 118: 1344-1354.

49. Falguera M, et al. Nonsevere community-acquired pneumonia: correlation between cause and severity or comorbidity. Archives of Internal Medicine 2001; 161: 1866-1872.

50. Saito A, et al. Prospective multicenter study of the causative organisms of community-acquired pneumonia in adults in Japan. Journal of Infection and Chemotherapy 2006; 12: 63-69.

51. Beović B, et al. Aetiology and clinical presentation of mild community-acquired bacterial pneumonia. European Journal of Clinical Microbiology \& Infectious Diseases 2003; 22: 584-591.

52. Gutiérrez F, et al. Community-acquired pneumonia of mixed etiology: prevalence, clinical characteristics, and outcome. European Journal of Clinical Microbiology \& Infectious Diseases 2005; 24: 377-383.

53. Strålin K, et al. Definite, probable, and possible bacterial aetiologies of community-acquired pneumonia at different CRB-65 scores. Scandavian Journal of Infectious Diseases 2010; 42: 426-434.

54. Kuzman I, et al. Clinical efficacy and safety of a short regimen of azithromycin sequential therapy vs standard cefuroxime sequential therapy in the treatment of community-acquired pneumonia: an international, randomized, open-label study. Journal of Chemotherapy 2005; 17: 636-642.
55. Briones ML, et al. Assessment of analysis of urinary pneumococcal antigen by immunochromatography for etiologic diagnosis of community-acquired pneumonia in adults. Clinical and Vaccine Immunology 2006; 13: 1092-1097.

56. Sohn JW, et al. Atypical pathogens as etiologic agents in hospitalized patients with community-acquired pneumonia in Korea: a prospective multi-center study. Journal of Korean Medical Science 2006; 21: 602-607.

57. Ishida T, et al. A 3-year prospective study of a urinary antigen-detection test for Streptococcus pneumoniae in community-acquired pneumonia: utility and clinical impact on the reported etiology. Journal of Infection and Chemotherapy 2004; 10: 359-363.

58. Ewig S, et al. Factors associated with unknown aetiology in patients with community-acquired pneumonia. European Respiratory Journal 2002; 20: 1254-1262.

59. Ishiguro T, et al. Etiology and factors contributing to the severity and mortality of community-acquired pneumonia. Internal Medicine 2012; 52: 317-324.

60. Díaz A, et al. Etiology of community-acquired pneumonia in hospitalized patients in Chile: the increasing prevalence of respiratory viruses among classic pathogens. Chest 2007; 131: 779-787.

61. Charles PGP, et al. The etiology of communityacquired pneumonia in Australia: why penicillin plus doxycycline or a macrolide is the most appropriate therapy. Clinical Infectious Diseases 2008; 46: 1513-1521.

62. Walden AP, et al. Patients with community acquired pneumonia admitted to European intensive care units: an epidemiological survey of the GenOSept cohort. Critical Care 2014; 18: 1-9.

63. Miyashita N, et al. Clinical features and the role of atypical pathogens in nursing and healthcare-associated pneumonia (NHCAP): differences between a teaching university hospital and a community hospital. Internal Medicine 2012; 51: 585-594.

64. Bütün Y, et al. Chlamydia and Mycoplasma serology in respiratory tract infections of children. Tüberküloz ve Toraks Dergisi 2006; 54: 254-258.

65. Capelastegui A, et al. Etiology of community-acquired pneumonia in a population-based study: link between etiology and patients characteristics, process-of-care, clinical evolution and outcomes. BMC Infectious Diseases 2012; 12: 134.

66. Spoorenberg SMC, et al. Chlamydia psittaci: a relevant cause of community-acquired pneumonia in two Dutch Hospitals. Netherlands Journal of Medicine 2016; 74: $75-81$.

67. van Gageldonk-Lafeber AB, et al. The aetiology of community-acquired pneumonia and implications for patient management. Netherlands Journal of Medicine 2013; 71: 418-425.

68. Huijskens EGW, et al. Viral and bacterial aetiology of community-acquired pneumonia in adults. Influenza and Other Respiratory Viruses 2012; 7: 567-573.

69. Dumke R, et al. Mycoplasma pneumoniae and Chlamydia spp. infection in community-acquired pneumonia, Germany, 2011-2012. Emerging Infectious Diseases 2015; 21: 426-433. 
70. Raeven VM, et al. Atypical aetiology in patients hospitalised with community-acquired pneumonia is associated with age, gender and season; a data-analysis on four Dutch cohorts. BMC Infectious Diseases 2016; 16: 299.

71. Rozenbaum MH, et al. Incidence, direct costs and duration of hospitalization of patients hospitalized with community acquired pneumonia: a nationwide retrospective claims database analysis. Vaccine 2015; 33: 3193-3199.
72. Snijders B, et al. General practitioners' contribution to the management of community-acquired pneumonia in the Netherlands: a retrospective analysis of primary care, hospital, and national mortality databases with individual data linkage. Primary Care Respiratory Journal 2013; 22: 400-405.

73. Cunha BA. The atypical pneumonias: clinical diagnosis and importance. Clinical Microbiology and Infection 2006; 12(Suppl 3): 12-24. 